\title{
Inhibition of lipid peroxidation and iron (II)-dependent DNA damage by extracts of Pothomorphe peltata (L.) Miq.
}

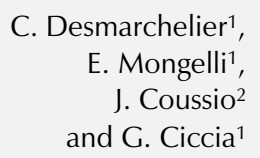

C. Desmarchelier ${ }^{1}$, E. Mongelli ${ }^{1}$, J. Coussio ${ }^{2}$ and G. Ciccia ${ }^{1}$

\author{
${ }^{1}$ Cátedra de Biotecnología y Microbiología Industrial and \\ ${ }^{2}$ Cátedra de Farmacognosia, IQUIMEFA-CONICET, \\ Facultad de Farmacia y Bioquímica, \\ Universidad de Buenos Aires, 1113 Buenos Aires, Argentina
}

\author{
Correspondence \\ C. Desmarchelier \\ Cátedra de Biotecnología y \\ Microbiología Industrial \\ Facultad de Farmacia y Bioquímica \\ Universidad de Buenos Aires \\ Junín 956 \\ 1113 Buenos Aires \\ Argentina \\ Fax: (541) 961-7637 \\ E-mail: cristian@bioen.ffyb.uba.ar \\ Research supported by CONICET \\ (Consejo Nacional de \\ Investigaciones Científicas y \\ Técnicas) and Universidad de \\ Buenos Aires.
}

Received April 22, 1996 Accepted September 25, 1996

\begin{abstract}
Leaves of Pothomorphe peltata (L.) Miq. (Piperaceae) are used locally as anti-inflammatory, antipyretic, hepatoprotective and diuretic infusions and to treat external ulcers and local infections in several parts of the Peruvian, Bolivian and Brazilian Amazon region. The antioxidant activity of different extracts of $P$. peltata was studied using the hydroperoxide-initiated chemiluminescence assay in liver homogenates, and the methanolic extract was found to have the highest antioxidant activity, with an $\mathrm{IC}_{50}=4 \mu \mathrm{g} / \mathrm{ml}$. Aqueous and dichloromethane extracts did not show antioxidant activity. The extracts were further evaluated using the thiobarbituric acid-reactive substances (TBARS) assay. Finally, an assay of DNA sugar damage induced by $\mathrm{Fe}$ (II) salt was used to determine the capacity of the extracts to suppress the oxidative degradation of DNA. All the extracts showed antioxidant activity in the latter two bioassays. The methanolic extract showed the highest activity in reducing oxidative damage to DNA, with an $\mathrm{IC}_{50}=5 \mu \mathrm{g} / \mathrm{ml}$. Since this extract was highly effective in reducing chemiluminescence and DNA damage, and because the latter activity could be due to the presence of compounds that bind to DNA, DNA-binding activity was studied using the DNAmethyl green (DNA-MG) bioassay. A 30\% decrease in the initial absorbance of DNA-MG complex was observed in the methanolic extract at $1000 \mu \mathrm{g} / \mathrm{ml}$, suggesting the presence of compounds that bind to genetic material. No DNA-binding activity was observed in the aqueous or dichloromethane extracts.
\end{abstract}

\section{Introduction}

Oxygen radicals and other reactive species derived from them are generated in biological systems either as by-products of oxygen reduction or by xenobiotic catabolism (1). These active oxygen molecules such as superoxide radicals $\left(\mathrm{O}_{\overline{2}}^{\bar{\gamma}}, \cdot \mathrm{OOH}\right)$ and hydroxyl radicals $(\cdot \mathrm{OH})$ are involved in infectious diseases, in local infections and in inflammatory diseases (2), and exert various deleterious effects in
Key words

- Pothomorphe peltata

- Antioxidant activity

- Hydroperoxide-initiated chemiluminescence

- Thiobarbituric acid-reactive substances

- DNA-binding activity

- Lipid peroxidation
....................

cells and tissues that basically depend on the subcellular structure where they are generated (3). When these species are generated within the hydrophobic domains of cell membranes, the free radical chain reaction of lipid peroxidation predominates. Lipid peroxidation products, e.g., phospholipids and fatty acid hydroperoxides, aldehydes and ketones contribute to the toxic effects exerted in hydrophobic domains $(1,3,4)$. It has been observed that DNA is also a major target of oxidative injury (5), 
being of particular importance in a large number of disorders such as cancer (6) and degenerative diseases including Alzheimer's disease, Parkinson's disease and Hodgkin's disease (7).

Pothomorphe peltata (L.) Miq. (Piperaceae) leaves are popularly used as anti-inflammatory (8-10), antipyretic (11), hepatoprotective (10) and diuretic $(11,12)$ infusions and to treat external ulcers and local infections $(13,14)$ in several parts of the Peruvian, Bolivian and Brazilian Amazon region. The generation and subsequent involvement of free radicals in a large number of diseases such as inflammatory and hepatic disorders have led us to study the effect of crude extracts of $P$. peltata against lipid and DNA oxidative damage. For this purpose, the inhibition of lipid peroxidation was measured using two different methods, namely the hydroperoxide-initiated chemiluminescence and the production of thiobarbituric acid-reactive substances (TBARS) in rat liver homogenates. DNA damage, on the other hand, was assessed in terms of the iron (II)dependent damage to DNA deoxyribose. Finally, the DNA-binding activity was determined by means of the DNA-methyl green (DNA-MG) assay. The data obtained suggest that extracts of $P$. peltata may protect against lipid peroxidation and oxidative DNA degeneration.

\section{Material and Methods}

\section{Chemicals}

tert-Butyl hydroperoxide (t-BOOH), catechin, thiobarbituric acid (TBA), butylated hydroxytoluene (BHT), phosphotungstic acid, bovine serum albumin acid, trichloroacetic acid (TCA), calf thymus DNA, DNA-methyl green and doxorubicin hydrochloride (Sigma Chemical Co., St. Louis, MO), sodium dodecyl sulfate (SDS) (Mann Research Laboratories Inc., New York), dichloromethane (Dorwill, Buenos Aires, Argentina), methanol, ethanol and ferrous ammonium sulfate (Mallinckrodt, New York), dimethylsulfoxide (DMSO), n- butanol and TCA (Merck, Buenos Aires, Argentina) were of analytical grade.

\section{Plant material}

Plant leaves were collected in the settlement of Filadelfia, on the Tambopata river, in Madre de Dios, Perú. Botanical identification was made by Dr.A.A. Gurni, Cátedra de Farmacobotánica, Facultad de Farmacia y Bioquímica, Universidad de Buenos Aires. A voucher specimen is deposited at this institution.

\section{Plant extracts}

Extracts were prepared following the recommendations of the CYTED (15). Infusions were made by pouring $100 \mathrm{ml}$ of boiling water on $5 \mathrm{~g}$ of powdered plant material placed in a stoppered flask. The mixture was left to stand for $20 \mathrm{~min}$ and then filtered. The resulting infusion was freeze-dried in a Gamma A lyophilizer (Chriss, Germany) and the resulting powder was considered to be the aqueous extract.

Dichloromethane extracts were prepared by extracting $5 \mathrm{~g}$ of dry powdered plant material for $24 \mathrm{~h}$ at room temperature in a stoppered flask with $50 \mathrm{ml}$ dichloromethane. The extract was filtered and concentrated under reduced pressure at $43^{\circ} \mathrm{C}$ in a Savant Speed Vac Plus SC210A concentrator. The marc was extracted with methanol under the same conditions as described for the dichloromethane extract. DMSO was used to solubilize the dichloromethane and methanolic extracts.

\section{Animals}

Adult Wistar rats (180-200 g) received a standard laboratory diet and water ad libitum.

\section{Preparation of rat liver homogenates}

The livers were excised, perfused and homogenized with $120 \mathrm{mM} \mathrm{KCl}$ and $50 \mathrm{mM}$ sodium phosphate buffer, $\mathrm{pH} 7.4,(1: 10, \mathrm{w} / \mathrm{v})$. The samples were centrifuged at $700 g$ for 10 
min at $0-4^{\circ} \mathrm{C}$. The supernatant fraction was kept at $-20^{\circ} \mathrm{C}$ until use.

\section{Protein determination}

Protein was measured by the Lowry et al. (16) method using bovine serum albumin as the standard.

\section{Hydroperoxide-initiated chemiluminescence}

Hydroperoxide-initiated chemiluminescence of liver homogenates (17) was measured in an LKB Wallac 1209 Rackbeta liquid scintillation counter in the out-of-coincidence mode, at $30^{\circ} \mathrm{C}$. Rat liver homogenates adjusted to a final protein concentration of $0.5 \mathrm{mg} / \mathrm{ml}$ in 120 $\mathrm{mM} \mathrm{KCl}$ and $50 \mathrm{mM}$ sodium phosphate buffer, $\mathrm{pH} 7.4$, in a final volume of $2 \mathrm{ml}$ were placed in $10 \times 35-\mathrm{mm}$ glass tubes, which were inserted into low potassium 25 x 50 -mm glass vials. Plant extracts solubilized in distilled water were adjusted to the reaction medium at 10, 100 and $1000 \mu \mathrm{g} / \mathrm{ml}$. DMSO was used to solubilize the dichloromethane and methanolic extracts. Chemiluminescence was initiated by the addition of $3 \mathrm{mM}$ tert-butyl hydroperoxide and is reported as cps/mg protein. Chemiluminescence inhibition values are reported as the ratio of the maximum emission in the presence of plant extracts to that in their absence (control). Catechin was used as a positive control or standard due to its high antioxidant activity (18). Finney's (19) statistical method of probit analysis was used to calculate the concentration of the extract that would inhibit chemiluminescence in $50 \%$, i.e., $\mathrm{IC}_{50}$.

\section{Thiobarbituric acid-reactive substances assay}

TBARS were determined by the method described in Fraga et al. (20). Rat liver homogenates, adjusted to $10 \mathrm{mg}$ protein/ml in 120 $\mathrm{mM} \mathrm{KCl}$ and $50 \mathrm{mM}$ sodium phosphate buffer, $\mathrm{pH}$ 7.4, were incubated with 1000, 100 and 10 $\mu \mathrm{g}$ dry weight $/ \mathrm{ml}$ of plant extract at $37^{\circ} \mathrm{C}$ for 15 min. Sodium dodecyl sulfate $(0.2 \mathrm{ml} 3 \%(\mathrm{w} / \mathrm{v}))$ and $0.05 \mathrm{ml} \mathrm{4 \%} \mathrm{BHT} \mathrm{in} \mathrm{ethanol} \mathrm{were} \mathrm{added.}$ After mixing, $2 \mathrm{ml} 0.1 \mathrm{~N} \mathrm{HCl}, 0.3 \mathrm{ml} \mathrm{10 \%}$ (w/ v) phosphotungstic acid and $1 \mathrm{ml} 0.7 \%(\mathrm{w} / \mathrm{v})$ 2-thio-barbituric acid were added. The mixture was heated for $60 \mathrm{~min}$ in boiling water, and TBARS were extracted into $5 \mathrm{ml} \mathrm{n}$-butanol. After centrifugation, the fluorescence of the butanol layer was measured at $515 \mathrm{~nm}$ excitation and $555 \mathrm{~nm}$ emission using Hitachi F3010 fluorescence spectrophotometer. The values are reported as the ratio of the amount of TBARS formed in the presence of plant extracts compared to control. Catechin was used as standard and 4,4 tetramethoxypropane was used as assay control. The extract concentration that would inhibit by $50 \%$ the thiobarbituric acid-reactive substances production, i.e., the $\mathrm{IC}_{50}$ with a $95 \%$ confidence interval, was calculated using Finney's (19) statistical method of probit analysis.

\section{Assay of DNA-sugar damage}

The DNA-sugar damage was assayed by the method of Halliwell and Gutteridge (21), with modifications. The reaction mixture in a total volume of $1.2 \mathrm{ml}$ contained $0.5 \mathrm{ml}$ calf thymus DNA ( $1 \mathrm{mg} / \mathrm{ml} 0.15 \mathrm{M} \mathrm{NaCl}), 0.5 \mathrm{ml}$ sodium phosphate buffer (0.1 M, pH 7.4), 0.2 $\mathrm{ml}$ ferrous ammonium sulfate $(4.8 \mathrm{mM})$ and 1000, 100 and $10 \mu \mathrm{g} / \mathrm{ml}$ of the methanolic plant fraction. The reaction mixture was incubated for $1 \mathrm{~h}$ at $37^{\circ} \mathrm{C}$ in a water bath shaker. Afterincubation, $1 \mathrm{ml}$ 1\% (w/v) TBA plus $1 \mathrm{ml}$ $2.8 \%(\mathrm{w} / \mathrm{v})$ TCA was added to the reaction mixture which was kept in a boiling water bath for $15 \mathrm{~min}$. The TBA reacting species so generated were extracted into $2 \mathrm{ml} \mathrm{n}$-butanol. After centrifugation, the fluorescence of the butanol layer was measured as described above. The iron (II)-dependent DNA-sugar damage inhibition values are reported as the ratio of TBA reacting species in the presence of plant extracts to that in their absence (control). Catechin was used as a positive control, and Finney's (19) statistical method of probit analysis was used to calculate the $\mathrm{IC}_{50}$. 
Table 1 - Antioxidant activity in extracts of $P$. peltata using the hydroperoxide-initiated chemiluminescence assay.

Inhibition of chemiluminescence was calculated by [1 - $(E s m / E c m)] \times 100$. Esm: emission intensity of test samples at maximum emission; Ecm: emission intensity of the control at maximum emission. Catechin was used as a standard. A negative value for inhibition indicates an increase in light emission compared with controls. ND, Not determined.

\begin{tabular}{lccccc}
\hline Extracts & \multicolumn{3}{c}{ Inhibition of chemiluminescence (\%) } & \multirow{2}{\text{IC}}{$\begin{array}{c}50(\mu \mathrm{g} / \mathrm{ml}) \text { and } 90 \% \\
\text { confidence interval }\end{array}$} \\
\cline { 2 - 4 } & $1000 \mu \mathrm{g} / \mathrm{ml}$ & $100 \mu \mathrm{g} / \mathrm{ml}$ & $10 \mu \mathrm{g} / \mathrm{ml}$ & $1 \mu \mathrm{g} / \mathrm{ml}$ & \\
\hline Catechin (control) & 85 & 81 & 73 & 49 & $1.00(0.1-2.7)$ \\
Aqueous & -247 & -253 & -32 & - & ND \\
Dichloromethane & -68 & 65 & 32 & - & ND \\
Methanolic & 73 & 68 & 61 & 38 & $4.00(0.8-11)$
\end{tabular}

\section{DNA-methyl green bioassay}

Interaction with DNA was determined using the method of Burres et al. (22). Sample solutions containing 10,100 and $1000 \mu \mathrm{g}$ of the corresponding methanolic extract per $\mathrm{ml}$ of ethanol were used. Twenty $\mu$ of the sample solutions to be tested was transferred in triplicate to the wells of a 96-well microplate (Kartell, Milan, Italy) and the solvent was removed under vacuum. Twenty mg of DNA-MG was suspended in $100 \mathrm{ml} 50 \mathrm{mM}$ Tris- $\mathrm{HCl}$ buffer, $\mathrm{pH} 7.5$, containing $7.5 \mathrm{mM} \mathrm{MgSO}_{4}$, and stirred at $37^{\circ} \mathrm{C}$ during $24 \mathrm{~h}$. Two hundred $\mu \mathrm{l}$ of DNAMG reagent was added to each well. The initial absorbance of each sample was read at $655 \mathrm{~nm}$ using a Biorad Microplate Model 450 Reader (Biorad, Richmond, VA). Samples were incubated in the dark at room temperature. After 24 $\mathrm{h}$, the final absorbance of samples was measured as described above. The decrease in absorbance was calculated as percent of the untreated DNA-MG absorbance value. Doxorubicin hydrochloride was used as a positive control.

\section{Results and Discusion}

The determination of tert-butyl hydroperoxide-initiated chemiluminescence proved to be a sensitive assay that could be applied to detect antioxidant activity in extracts of $P$. peltata. Table 1 shows the inhibition of light emission observed in rat liver homogenates. Results are reported as percent inhibition evaluated at maximum emission (23), while negative inhibition values are the result of increasing chemiluminescence. The methanolic extract of $P$. peltata showed high antioxidant activity at different concentration (Figure 1), while the dichloromethane extract was only effective at the lowest concentrations (10 and $100 \mu \mathrm{g} / \mathrm{ml})$. The aqueous extract caused an increase in chemiluminescence.

Because hydroperoxide-initiated chemiluminescence detects the free radical trapping activity in a chain reaction that occurs both in the hydrophilic and the hydrophobic domains of biological membranes, a second assay that measures the production of malondialdehyde and related compouds was performed. TBARS are produced as by-products of lipid peroxidation that occurs in the hydrophobic core of biomembranes (20). Although all the extracts tested showed the ability to reduce lipid peroxidation by this method (Table 2), no significant differences were observed between them. Hydroperoxide-initiated chemiluminescence was more sensitive than TBARS production to determine changes in lipid peroxidation, as reported previously (24-26). Similarly, catechin was highly effective in inhibiting the hydroper- 
oxide-initiated chemiluminescence (Table 1), and less effective as an inhibitor of TBARS production (Table 2).

DNA is also a major target of free radicalinduced damage. Under physiological conditions the constant and endogenous rate of production of free radicals may lead to a minimal damage in DNA which is needed to induce the defensive systems and DNA-repair mechanisms. However, if this production increases, oxygen radicals may attack DNA at either the sugar (deoxyribose) or the base, giving rise to a large number of products. Attack at a sugar ultimately leads to strand break with a terminal fragmented sugar residue (27). Protection by different extracts of $P$. peltata against DNA damage was determined in terms of the damage to its deoxyribose sugar moiety. The presence of various concentrations (10-1000 $\mu \mathrm{g}$ / $\mathrm{ml}$ ) of $P$. peltata extracts prevented the free radical-mediatedDNA-sugar damage in a dosedependent manner (Table 3). Although all the extracts showed antioxidant activity, the methanolic extract was the most effective. Catechin was also highly effective in reducing DNA oxidation. The concentration of the methanolic extract that inhibited DNA-damage by $50 \%$, i.e., the $\mathrm{IC}_{50}$, was $5 \mu \mathrm{g} / \mathrm{ml}$. This value was similar to the $\mathrm{IC}_{50}$ obtained for catechin, suggesting the presence of compound(s) with high antioxidant activity, since the material under study was a crude extract. Based on the preliminary data obtained, we postulate that leaves of $P$. peltata may contain compounds that are capable of acting as antioxidants by reducing lipoperoxidation and free radical-induced DNA-damage.

The antioxidant activity of $P$. peltata extracts was determined using three different bioassays. The determination of chemiluminescence is qualitatively different in that it is used to determine oxidative stress associated with the existence of an imbalance between antioxidant and prooxidant compounds present in the reaction mixture (17). Unknown compounds present in the aqueous extractcould diminish the antioxidant activity of certain hy-

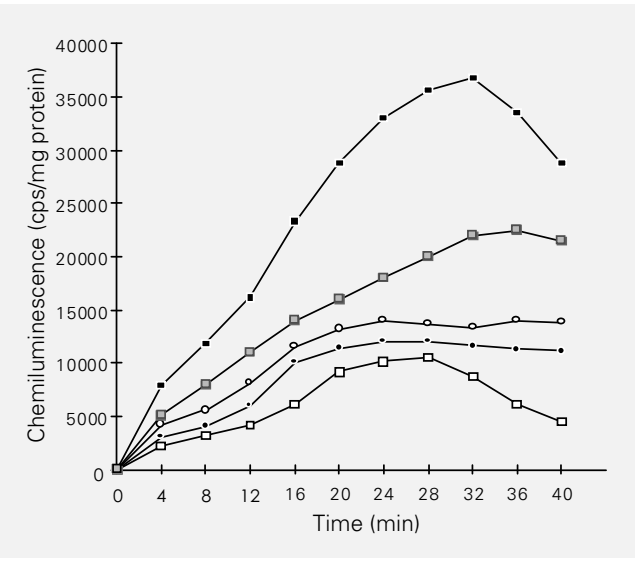

Figure 1 - Effect of a methanolic extract of $P$. peltata on the time course of hydroperoxide-initiated chemiluminescence in rat liver homogenates. ., No addition; $\square, 1000 \mu \mathrm{g} / \mathrm{ml} ; \bullet, 100 \mu \mathrm{g} /$ $\mathrm{ml} ; \mathrm{O}, 10 \mu \mathrm{g} / \mathrm{ml}$, and $\mathrm{\square}, 1 \mu \mathrm{g} / \mathrm{ml}$. Zero time was the moment of tert-butyl hydroperoxide addition. Values reported are the mean of 2 determinations.

drophilic antioxidants present in liver homogenates, such as glutathione and vitamin $\mathrm{C}$. This would lead to an imbalance in the direction of oxidative stress and the consequent increase in chemiluminescence observed for the aqueous extract (Table 1). In contrast, the increase in chemiluminescence observed at high concentrations of the dichloromethane extract may also be due to the presence of antioxidants that lose their activity at high concentrations, such as desferrioxamine. Finally, the antioxidants present in aqueous and dichloromethane extracts responsible for the inhibition of the production of TBARS (Table 2) may not be implicated in the main pathway of the hydroperoxide-initiated chain reaction, which leads to modifications in light emission, and therefore do not decrease the intensity of chemiluminescence. This is the case for some enzymatic antioxidants such as superoxide dismutase (SOD) and catalase, which in previous studies

Table 2 - Inhibition of the production of thiobarbituric acid-reactive substances (TBARS) by extracts of $P$. peltata.

Percent of inhibition was calculated by (1 - Ptm/Pcm) x 100. Ptm: production of TBARS by test samples; Pcm: production of TBARS by controls. Catechin was used as a standard.

\begin{tabular}{lcccc}
\hline Extracts & \multicolumn{3}{c}{ Inhibition (\%) } & \multirow{2}{}{$\begin{array}{c}\mathrm{C}_{50}(\mathrm{\mu g} / \mathrm{ml}) \text { and } 95 \% \\
\text { confidence interval }\end{array}$} \\
\cline { 2 - 4 } & $1000 \mu \mathrm{g} / \mathrm{ml}$ & $100 \mu \mathrm{g} / \mathrm{ml}$ & $10 \mu \mathrm{g} / \mathrm{ml}$ & \\
\hline Catechin (control) & 55 & 55 & 45 & $46(78-22)$ \\
Aqueous & 58 & 22 & 6 & $631(1190-396)$ \\
Dichloromethane & 47 & 46 & 6 & $638(1668-339)$ \\
Methanolic & 37 & 21 & 10 & \\
\end{tabular}


Table 3 - Effect of $P$. peltata extracts on free radical-mediated DNA-sugar damage and catechin-equivalent activity.

Percent of inhibition of iron (II)-mediated DNA-sugar damage was calculated by (1 - Dtm/Dcm) x 100. Dtm: fluorescence in test samples; Dcm: fluorescence in controls. Catechin was used as a standard. Catechinequivalent activity was calculated as described in the legend to Table 1.

\begin{tabular}{|c|c|c|c|c|c|c|c|}
\hline \multirow[t]{2}{*}{ Extracts } & \multicolumn{3}{|c|}{ Inhibition (\%) } & \multicolumn{3}{|c|}{$\begin{array}{c}\text { Catechin-equivalent } \\
\text { activity (\%) }\end{array}$} & \multirow[t]{2}{*}{$\begin{array}{l}\mathrm{I}_{50}(\mu \mathrm{g} / \mathrm{ml}) \text { and } 95 \% \\
\text { confidence interval }\end{array}$} \\
\hline & $1000 \mu \mathrm{g} / \mathrm{ml}$ & $00 \mu \mathrm{g} / \mathrm{ml}$ & $0 \mu \mathrm{g} / \mathrm{ml}$ & $1000 \mu \mathrm{g} / \mathrm{ml}$ & $100 \mu \mathrm{g} / \mathrm{ml}$ & $10 \mu \mathrm{g} / \mathrm{ml}$ & \\
\hline Catechin (control) & 93 & 74 & 59 & 100 & 100 & 100 & $5.00(12.7-1.3)$ \\
\hline Aqueous & 30 & 20 & 16 & 32 & 27 & 27 & $>1000$ \\
\hline Dichloromethane & 31 & 22 & 14 & 33 & 30 & 24 & $>1000$ \\
\hline Methanolic & 87 & 74 & 56 & 94 & 100 & 95 & $5.00(12.95-0.72)$ \\
\hline
\end{tabular}

were shown to be unable to affect chemiluminescence at higher concentrations (17).

Nuclear and mitochondrial DNA are damaged in vivo by free radicals generated either in normal cellular metabolism pathways and by the action of inflammatory phagocytes in neighboring cells, or by the action of exogenous agents, such as mutagens and radiation, which also induce the production of free radicals. Antioxidants present in $P$. peltata could act either by scavenging free radicals produced in the inflammatory process or by protecting DNA against the oxidative damage induced by these free radicals. Since the latter activity could be mediated by the presence of compounds that bind to DNA, a colorimetric bioassay for the detection of agents that interact with DNA was carried out. A 30\% decrease in the initial absorbance of the DNA-MG complex was observed in the presence of methanolic extract at $1000 \mu \mathrm{g} / \mathrm{ml}$. No DNA-binding activity was observed in the aqueous or dichloromethane extract in comparison with the reference compound, doxorubicin.

Plants are the source of a wide variety of compounds with a potential antioxidant activity, such as flavonoids and polyphenols. These compounds encompass a substantial molecular weight range, which provides them with different water solubilities. Oxidative stress in the cytosol can be combated with hydrophobic antioxidants due to the presence of hydropho- bic domains in the celular cytoplasm. In contrast, the nucleus is an aqueous domain, and the antioxidants which are to act there should therefore be water soluble. It has been suggested that the antioxidant property of compounds present in plant extracts or their metal sequestering property due to the presence of polyphenol compounds might be responsible for these effects (28). Thus, the study of crude extracts has proved to be advantageous in that it can help in the designing of modern plant medicinal products which are closer to the original medications commonly used by general populations, resulting in scientific validation of the ethnomedical ancestral use (29). Furthermore, it is important to note that the isolation of an active compound may not always qualitatively or quantitatively account for the activity of the total plant extract, since this may be determined by synergistic mechanisms which are frequently observed in the study of natural products (30). The nature of the compounds present in leaves of $P$. peltata and the mechanism by which they prevent oxidative injury to lipids and DNA need to be further evaluated in order to determine their potential activity in vivo.

\section{Acknowledgments}

The authors wish to thankDr. SusanaLlesuy for her useful advice. 


\section{References}

1. Chance B, Sies H \& Boveris A (1979). Hydroperoxide metabolism in mammalian organs. Physiological Reviews, 59: 527605.

2. Bast A \& Goris R (1989). Oxidative stress. Biochemistry and human disease. Pharmaceutisch Weekblad Scientific Edition, 11: 199-206

3. Sies H (1985). Oxidative stress: Introductory remarks. In: Sies H (Editor), Oxidative Stress. Academic Press, Orlando.

4. Esterbauer H (1985). Lipid peroxidation products: formation, chemical properties and biological activities. In: Poli G, Cheeseman K, Dianzani U \& Slater T (Editors), Free Radicals in Liver Injury. FRL Press, Oxford.

5. Ames B (1989). Endogenous oxidative DNA damage, aging and cancer. Free Radical Biology and Medicine, 121-125.

6. Emerit $Y$ \& Cerutti $P$ (1981). Clastogenic activity from Bloom syndrome fibroblast cultures. Proceeding of the National Academy of Sciences, USA, 78: 1868-1872.

7. Jenner $P$ (1991). Oxidative stress as a cause of Parkinson's disease. Acta Neurologica Scandinavica, 84: 6-15.

8. Tournon J, Serrano G, Reátegui U \& Albán $J$ (1986). Plantas y árboles medicinales de los Conibo del Alto Ucayali: concepciones nativas y botánica. Revista Forestal del Perú, 13: 107-130.

9. de Feo V (1991). Uso di piante ad azione antiinflammatoria nell'Alto Ucayali, Perú Orientale. Fitoterapia, 62: 481-494.

10. Di Stasi L, Hiruma C, Guimaraes E \& Santos C (1994). Medicinal plants popularly used in Brazilian Amazon. Fitoterapia, 65: 529-540.

11. Rutter R (1990). Catálogo de Plantas Utiles de la Amazonía Peruana. 2nd edn. Instituto Linguístico de Verano, Lima, Perú.
12. Soukup J (1987). Vocabulario de los Nombres Vulgares de la Flora Peruana y Catálogo de los Géneros. 2nd. edn. Editorial. Salesiana, Lima, Perú.

13. Desmarchelier C, Gurni A, Ciccia G \& Giulietti A (1996). Ritual and medicinal plants of the Ese'ejas of the Amazonian rainforest (Madre de Dios, Perú). Journal of Ethnopharmacology, 52: 45-51.

14. Desmarchelier C, Mongelli E, Giulietti A, Coussio J \& Ciccia G (1995). Etnobotánica y bioactividad de plantas medicinales utilizadas por un grupo indígena Takana de la Amazonía peruana. Acta Farmacéutica Bonaerense, 14: 195-208.

15. Anonymous (1995). Manual de Técnicas de Investigación. Programa Iberoamericano de Ciencias y Tecnología para el Desarrollo, Madrid.

16. Lowry O, Rosebrough A, Farr A \& Randall $R$ (1951). Protein measurement with the Folin phenol reagent. Journal of Biological Chemistry, 193: 265-275.

17. Gonzalez Flecha B, Llesuy S \& Boveris A (1991). Hydroperoxide-initiated chemiluminescence: an assay for oxidative stress in biopsies of heart, liver and muscle. Free Radical Biology and Medicine, 10: 93-100.

18. Fraga C, Martino V, Ferraro G, Coussio J \& Boveris A (1987). Flavonoids as antioxidants evaluated by in vitro and in situ liver chemiluminescence. Biochemical Pharmacology, 36: 717-720.

19. Finney D (1971). Probit Analysis. Cambridge University Press, Cambridge.

20. Fraga C, Leibovitz B \& Tappel A (1987). Halogenated compounds as inducers of lipid peroxidation in tissue slices. Free Radical Biology and Medicine, 3: 119-123.

21. Halliwell B \& Gutteridge J (1981). Formation of a thiobarbituric-acid-reactive substance from deoxyribose in the presence of iron salts. The role of superoxide and hydroxyl radicals. FEBS Letters, 128: 347352.
22. Burres N, Frigo A, Rasmussen R \& McAlpine J (1992). A colorimetric microassay for the detection of agents that interact with DNA. Journal of Natural Products, 55: 1582-1587.

23. Cadenas E \& Sies H (1982). Low leve chemiluminescence of liver microsomes fractions initiated by tert-butyl hydroperoxide. Relation to microsomal haemoproteins, oxygen dependence and lipid peroxidation. European Journal of Biochemistry, 124: 349-356.

24. Fernandez V, Llesuy S, Solari L, Kipreos K, Videla L \& Boveris A (1988). Chemiluminescent and respiratory response related to thyroid hormone-induced liver oxidative stress. Free Radical Research Communications, 5: 77-84.

25. Videla L, Fraga $C$, Koch $O$ \& Boveris A (1983). Chemiluminescence of the in situ rat liver after acute ethanol intoxication. Effect of (+)-cyanidanol-3. Biochemical Pharmacology, 32: 2822-2825

26. Lavagno C, Giulivi C \& Boveris A (1991). Betamethasone effects of Paraquat lung toxicity. Xenobiotica, 21: 1003-1011.

27. Imlay J \& Linn S (1988). DNA damage and oxygen radical toxicity. Science, 240: 1302-1309.

28. Sultana $S$, Perwaiz $S$, Iqbal $M$ \& Athar $M$ (1995). Crude extracts of hepatoprotective plants Solanum nigrum and Cichorium intybus inhibit free radical-mediated DNA damage. Journal of Ethnopharmacology, 45: 189-192.

29. Lozoya X (1996). Medicinal plants of Mexico: a program for their scientific validation. In: Balick M, Elisabetsky E \& Laird $S$ (Editors), Medicinal Resources of the Tropical Forest: Biodiversity and its Importance to Human Health. Columbia University Press, New York.

30. Houghton P (1995). The role of plants in traditional medicine and current therapy. Journal of Alternative and Complementary Medicine, 1: 131-143. 